GRASAS Y ACEITES, 62 (1), ENERO-MARZO, 105-110, 2011, ISSN: 0017-3495

DOI: $10.3989 /$ gya.055710

\title{
Antioxidant effects of an ozonized theobroma oil formulation on damaged-inflammatory rat skin
}

\author{
By Yaima Sánchez, ${ }^{a}$ Maritza F. Díaz, ${ }^{\mathrm{a}, \star}$ Frank Hernández, ${ }^{a}$ Dayana Gil ${ }^{\mathrm{a}}$ and Gastón García
}

\author{
${ }^{a}$ Ozonized Vegetable Oils Group. Ozone Researches Center. CNIC. 15 Avenue and 230 street, \\ Siboney, Playa, C. Havana, Cuba.

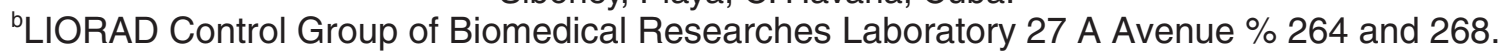 \\ La Lisa. Havana. Cuba \\ ( ${ }^{\star}$ Corresponding autor: maritza.diaz@cnic.edu.cu)
}

\begin{abstract}
RESUMEN
Efecto antioxidante de una formulación de aceite de teobroma ozonizado sobre la piel de ratas con daño inflamatorio.

El objetivo de este estudio fue determinar si una formulación cosmética elaborada con aceite de teobroma ozonizado puede ejercer efectos beneficiosos en la restauración de la actividad antioxidante sobre la piel de ratas previamente irradiadas con luz ultravioleta. Fue aplicada $0,5 \mathrm{~g}$ de la formulación sobre la piel de ratas durante cinco días. La actividad de las enzimas superóxido dismutasa (SOD), glutatión peroxidasa (GPx), y catalasa fueron determinadas en homogeneizado de piel de ratas. Los contenidos de malonildialdehído (MDA), dienos conjugados (DC) e hidroperóxidos totales (HPT) fueron considerados como los biomarcadores de daño oxidativo. Con todos estos parámetros fueron determinados las actividades antioxidantes y oxídantes, índice redox y grado de estrés oxidativo. La actividad antioxidante total fue incrementada significativamente, mientras que el índice redox, la actividad oxidante y el grado de estrés oxidativo disminuyó significativamente, en ratas dañadas tratadas con la formulación. Estos resultados evidencian las propiedades antioxidantes de la formulación cosmética debido a la estimulación de enzimas antioxidantes tales como SOD o GPx, previniendo el daño en la piel inducido por radiación ultravioleta.
\end{abstract}

PALABRAS CLAVE: Aceite de teobroma ozonizado Actividad antioxidante - Actividad oxidante - Estrés oxidativo - Formulación cosmética.

\section{SUMMARY}

Antioxidant effect of an ozonized theobroma oil formulation on damaged-inflammatory rat skin.

The aim of this study was to determine whether a cosmetic formulation elaborated with ozonized theobroma oil may exert beneficial effects in the restoring of the antioxidant activity on the skin of rats previously irradiated with ultraviolet light. 0.5 $\mathrm{g}$ of the formulation was applied on the skin of rats for five days. Superoxide dismutase (SOD), glutathione peroxidase (GPx) and catalase (CAT) activity were determined in a homogenate of rat skin. Malondialdehyde (MDA), conjugated dienes (CD) and total hydroperoxide (THP) content were determined as biomarkers of oxidative stress. Using these parameters, antioxidant and oxidant activity, redox index and oxidative stress grade were determined. The total antioxidant activity was significantly increased while the redox index, total oxidant activity and oxidative stress grade decreased significantly in damaged rats treated with the formulation. These results show the antioxidant properties of the cosmetic formulation due to the stimulation of antioxidant enzymes such as SOD and GPx, preventing skin injury induced by ultraviolet irradiation.

KEY-WORDS: Antioxidant activity - Cosmetic formulation - Oxidant activity - Oxidative stress - Ozonized theobroma oil.

\section{INTRODUCTION}

The increasing incidence of disorders in human skin is closely related, among other factors, to solar radiation, mainly because of the unwanted effects induced by ultraviolet radiations contained in the solar spectrum. Among the main effects induced by ultraviolet radiations are a highlighted increase in the formation of reactive oxygen species (ROS) and a decrease in the antioxidant capacity of the skin, which leads to an increase in the incidence of neoplasic and preneoplasic injuries (Southorn and Powis, 1988). At present, the continuous search for natural products that possess a high antioxidant activity for skin protection and the restoring of damages induced by ROS has become one of the major tendencies in medical science and cosmetology research (Pallack and Morse, 1988; Packer, 1994; Díaz and Hernández, 2008). When vegetable oils are ozonized a mixture of oxygenated compounds is obtained such as hydrogen peroxide and ozonides which are biologically active (Díaz et al., 2006 a,b). These compounds stimulate the enzymes related to reduction-oxidation processes, which represent an increase in the defensive capacity of the cell against ROS (Menéndez et al., 2008). When these oxygenated molecules come into contact with damaged skin, they slowly decompose to reactive ozone, wich readily dissolves in water, generating hydrogen peroxide and lipid oxidation products that could explain the stimulatory activity of the antioxidant defence system, in addition the skin is oxygenated. (Bocci, 2005)

One of the disadvantages of vegetable oils is that when they are ozonized, they acquire a very unpleasant odor; however theobroma oil that posseses 
a very nice odor in its natural form, when it is ozonized the resulting scent does not happen to be as strong as the smell of the other vegetable oils. This is the main reason for the choice of this oil for the elaboration of a cosmetic formulation.

During a clinical trial performed in the dermatological area of the Surgical Clinic Hospital "Dr Salvador Allende" (Cuba), the effect of a cosmetic formulation elaborated with ozonized theobroma oil was studied on the cutaneous aging disorder, which showed emollient, nutritious and antiwrinkle properties (Hasbún et al., 2005; Molerio et al., 2005). These results have permitted the Sanitary Register of this cosmetic formulation to be obtained (Díaz et al., 2008).

The development of treatments to avoid oxidative disorders related to aging is becoming more important every day; that is why the aim of this research is to determine the antioxidant activity of a cosmetic formulation elaborated with ozonized theobroma oil in the skin of rats with an oxidative injury. Results show the antioxidant properties of the cosmetic formulation by stimulating the antioxidant enzymes such as SOD and GPx, which prevent skin injury induced by ultraviolet radiation.

\section{MATERIALS AND METHODS}

\subsection{Experimental design}

Fifty male Sprague Dawley rats (180 - 200 g) were purchased from the National Center for Laboratory Animal Production (Cuba). Animals were kept in quarantine in an air-filtered, temperatureconditioned room $(20 \pm 20 \mathrm{C})$ with a relative humidity of $50 \pm 5 \%$. Rats were fed with standard laboratory chow and water ad libitum and were kept under an artificial light/dark cycle of 12 hours (EEC, 1979). This was carried out according to the ethical guidelines for research with laboratory animals and was approved by the Ethical Committee of Animal Experiments of the National Center for Scientific Research, Havana City, Cuba.

Animals were randomized in five groups: group I (negative control, animals without skin injury), group II (negative control + ozonized cosmetic formulation), group III (positive control, animals with skin injury), group IV (positive control + unozonized cosmetic formulation), group $\mathrm{V}$ (positive control + ozonized cosmetic formulation). Every animal was shaved the day before the experiment began. Animals from the negative control group were not irradiated. Animals from the positive control group were irradiated.

\subsection{Procedure}

Rats were shaved in a $6 \times 8 \mathrm{~cm} 2$ area of the inter-scapular zone, 24 hours before beginning the trial. Any damage to the animal skin was carefully avoided. Animals of groups III, IV and V were anesthetized using sodium thiopental at a $40 \mathrm{mg} /$ $\mathrm{kg}$ dose, to induce a skin erithema by means of exposure to ultraviolet radiation for fifteen minutes. The ultraviolet light lamp was used with a wave length between 290 and $315 \mathrm{~nm}$, at a distance of $10 \mathrm{~cm}$ from the skin.

Ozonized cosmetic and unozonized cosmetic formulations were directly applied on the damaged rat skin, spreading $0.5 \mathrm{~g}$ of the product daily for five days. Twenty-four hours after the treatment was concluded, animals were euthanized using ether overdose and skin samples were collected and washed in a saline solution (NaCL $0.9 \% \mathrm{w}-\mathrm{v}$ ). Samples were stored at $-20^{\circ} \mathrm{C}$ until the performance of biochemical determinations.

\subsection{Equipment}

Ultraviolet lamp Sunlamp ULTRALUX from the OSRAM presents a $220-230 \mathrm{~V}$ connection, power consumption $300 \mathrm{~W}$, and a filter containing two wavelengths of ultraviolet light (UVA and UVB)

\subsection{Cosmetic formulation}

Theobroma oil was supplied by the "Rubén David Suárez Abella" company of Cuba. A Cosmetic formulation with $10 \%$ ozonized theobroma oil and a vehicle in a sufficient amount to reach $100 \%$ was elaborated in the Ozone Research Center with peroxide index values between 90 and $130 \mathrm{mmol}-$ equiv of active $\mathrm{O} 2 / \mathrm{kg}$ of sample.

An Unozonized cosmetic formulation with 10\% theobroma oil and a vehicle in a sufficient amount to reach $100 \%$ was elaborated in the Ozone Research Center with peroxide index values between 3 and $10 \mathrm{mmol}$-equiv of active $\mathrm{O} 2 \mathrm{~kg}$ of sample.

\subsection{Sample treatment}

The skin samples were weighed and homogenized using a tissue destroyer (ULTRATURAX® T25 Polytron), at $4^{\circ} \mathrm{C}$. They were homogenized at least three times for thirty seconds, using a saline phosphate buffer in a proportion of $5 \% \mathrm{w}-\mathrm{v}$ or $10 \%$ $\mathrm{w}-\mathrm{v}$. The homogenates were centrifuged at $6000 \mathrm{~g}$ for 15 minutes at $4^{\circ} \mathrm{C}$. The supernatants were collected for biochemical analysis.

\subsection{Biochemical assays}

The biochemical parameters measured were: total proteins (Lowry et al., 1951), catalase (CAT) (Vanlente and Pepoy, 1990), superoxide dismutase (SOD) (Minami and Yoshikawa, 1979), gluthatione peroxidase (GPx) (Faraji et al., 1987), malondidialdehyde (MDA) (Gerard-Moonier et al., 1998), total hydroperoxides (THP) (Wolff, 1994) and conjugated dienes (CD) (Vasankari et al., 1995).

\subsection{Oxidative stress diagnosis system}

Oxidative stress diagnosis is carried out using a specific software developed in the Ozone Research Center of Cuba and registered in the Author Rights 
Office of Cuba (Hernández, 2006). This software has been programmed using the artificial neurons net technique, which is related to complex responses as they occur in the oxidative stress process. The software gives four new parameters which are shown in Table 1. It takes into account the reference parameters obtained from more than 250 healthy persons and the values obtained for different diseases related to oxidative stress. In the case of using the system in animals, it takes references from values obtained in control groups (Hernández, 2007), (Guanche et al., 2009). The clinical meaning for the oxidative stress grade is shown in Table 2 (Hernández, 2006).

\subsection{Statistical analysis}

Data were analyzed as main $\pm S D$ using the Statistical software package version 6.0 (Statistic, 2003). Differences among groups were analyzed by means of One Way Anova test; the Tukey (Honest Significant Difference HSD) test was carried out. Significance level was established in every case starting from $95 \%$.

\section{RESULTS}

The activities of the enzyme Catalase, Superoxide Dismutase and Gluthatione Peroxidase of all groups are shown in Table 3. Catalase activity was significantly increased in the positive control group compared to groups I, II and V. No significant differences were observed between groups III and IV. There was a significant increase in the activity of SOD in group $\mathrm{V}$ compared to the other groups, plus, the activity of this enzyme was inhibited in group III when it is compared with group I. On the other hand, the activity of GPx rises significantly in groups IV and V, while group III showed similar activity to that in group I

Values from the oxidant biomarkers in the five studied groups are shown in Table 4. It was observed that MDA level was significantly increased in group III. Groups IV and V displayed lower values than group III but higher than groups I and II. Group III exhibited the highest value of THP, there was a slight decrease in groups IV and V compared with group III, while groups I and II showed the lowest values. Regarding the CD values, the behavior was totally different: those groups that were not exposed to the oxidative stress (I and II) showed the highest values of CD, while groups III, IV and V showed the lowest values, with differences between groups III and V.

The results from the Oxidative Stress Diagnosis System are displayed in Table 5. Group V exhibited the highest antioxidant activity compared to the other groups; it is three times higher than antioxidant activity of group I. On the other hand oxidant activity is much higher in group III than in the other groups. Redox index was very low in group III compared with the other groups, showing statistical differences with groups I, II and V. It is worth noting that groups III and IV had the maximum value (4) of oxidative stress in the system, whereas group $\mathrm{V}$ had only a grade 1 , and group II a grade 0 .

\section{DISCUSSION}

Research focused on finding new products with a remarkable antioxidant activity have become an important objective at present day (Alvarez,

Table 1

Reference values of the oxidative stress diagnosis system (Hernández, 2007), (Guanche, 2009)

\begin{tabular}{cc}
\hline Parameters & Reference Values \\
\hline Total Antioxidant Activity (Units) & $132.37-172.37$ \\
Total Oxidant Activity (Units) & $125.15-169.58$ \\
Redox Index & $0.940-1.353$ \\
Oxidative Stress Grade & $0.0-0.5$ \\
\hline
\end{tabular}

Table 2

Meaning of the oxidative stress grades (Hernández, 2006)

\begin{tabular}{cc}
\hline Grade & Meaning \\
\hline $0(0.0-0.5)$ & No Oxidative Stress \\
$1(0.6-1.5)$ & Slight Oxidative Stress \\
$2(1.6-2.5)$ & Moderate Oxidative Stress \\
$3(2.6-3.5)$ & Severe Oxidative Stress \\
$4(3.6-4.0)$ & Very Severe Oxidative Stress \\
\hline
\end{tabular}


Table 3

Obtained results from antioxidant biomarkers in the five groups of studied rats

\begin{tabular}{cccc}
\hline Groups of animals & $\begin{array}{c}\text { CAT } \\
\text { (KU/g protein) }\end{array}$ & $\begin{array}{c}\text { SOD } \\
\text { (KU/g protein) }\end{array}$ & $\begin{array}{c}\text { GPx } \\
\text { (UI/g protein) }\end{array}$ \\
\hline Group I & $6.67 \pm 0.97 \mathrm{~cd}$ & $7092 \pm 1134 \mathrm{bce}$ & $4.88 \pm 0.51 \mathrm{bde}$ \\
Group II & $7.29 \pm 1.08 \mathrm{~cd}$ & $18566 \pm 478 \mathrm{acde}$ & $1.40 \pm 0.41 \mathrm{bde}$ \\
Group III & $12.95 \pm 1.45 \mathrm{abe}$ & $4122 \pm 211 \mathrm{abde}$ & $10.18 \pm 1.17 \mathrm{abce}$ \\
Group IV & $10.81 \pm 0.77 \mathrm{abe}$ & $8673 \pm 543 \mathrm{bce}$ & $13.92 \pm 0.68 \mathrm{abcde}$ \\
Group V & $6.10 \pm 0.58 \mathrm{~cd}$ & $28938 \pm 1350 \mathrm{abcd}$ &
\end{tabular}

CAT Catalase, SOD Superoxide dismutase, GPx Gluthatione peroxidase. Group I (negative control). Group II (negative control + ozonized cosmetic formulation). Group III (positive control). Group IV (positive control + unozonized formulation). Group V (positive control + ozonized cosmetic formulation). a $P<0.05$ compared to group I (negative control). b $P<0.05$ compared to group II (negative control + ozonized cosmetic formulation). $\mathrm{c} P<0.05$ compared to group III (positive control). $\mathrm{d} P<0.05 \mathrm{compared}$ to group IV (positive control + unozonized formulation). e $P<0.05$ compared to group V (positive control + ozonized cosmetic formulation).

Table 4

Obtained results from oxidant biomarkers in the five groups of studied rats

\begin{tabular}{|c|c|c|c|}
\hline $\begin{array}{l}\text { Groups } \\
\text { of animals }\end{array}$ & $\begin{array}{c}\text { MDA } \\
\text { ( } \mu \mathrm{mol} / \mathrm{g} \text { tissue) }\end{array}$ & $\begin{array}{c}\text { THP } \\
\text { ( } \mu \mathrm{mol} / \mathrm{g} \text { protein) }\end{array}$ & $\begin{array}{c}\text { CD } \\
\text { ( } \mu \mathrm{mol} \text { of } \mathrm{CD} / \mathrm{g} \text { tissue) }\end{array}$ \\
\hline Group I & $10.76 \pm 0.63 \mathrm{cde}$ & $1.19 \pm 0.11 \mathrm{cde}$ & $1748 \pm 92 b c d e$ \\
\hline Group II & $10.90 \pm 1.03 \mathrm{cde}$ & $1.92 \pm 0.46 \mathrm{cde}$ & $1261 \pm 33$ acde \\
\hline Group III & $34.98 \pm 2.53 a b d e$ & $9.00 \pm 0.37 a b e$ & $263 \pm 20$ abe \\
\hline Group IV & $18.03 \pm 0.97 a b c$ & $8.40 \pm 0.35 a b$ & $361 \pm 20 a b$ \\
\hline Group V & $17.80 \pm 0.60 a b c$ & $7.47 \pm 0.64 a b c$ & $462 \pm 23 a b c$ \\
\hline
\end{tabular}

MDA Malondidialdehyde, THP Total hydroperoxides, CD Conjugated dienes. Group I (negative control). Group II (negative control + ozonized cosmetic formulation). Group III (positive control). Group IV (positive control + unozonized formulation). Group V (positive control + ozonized cosmetic formulation). a $P<0.05$ compared to group I (negative control). bP $<.05$ compared to group II (negative control + ozonized cosmetic formulation). $\mathrm{c} P<0.05$ compared to group III (positive control). $\mathrm{d} P<0.05$ compared to group IV (positive control + unozonized formulation). e $P<0.05$ compared to group V (positive control + ozonized cosmetic formulation).

Table 5

Parameters obtained from Oxidative Stress Diagnosis System

\begin{tabular}{ccccc}
\hline $\begin{array}{c}\text { Groups } \\
\text { of Animals }\end{array}$ & $\begin{array}{c}\text { Total Antioxidant } \\
\text { Activity }\end{array}$ & $\begin{array}{c}\text { Total Oxidant } \\
\text { Activity }\end{array}$ & Redox Índex & $\begin{array}{c}\text { Oxidative Stress } \\
\text { Grade }\end{array}$ \\
\hline Group I & $154.83 \pm 22.61 \mathrm{bde}$ & $148.01 \pm 17.93 \mathrm{cde}$ & $1.068 \pm 0.25 \mathrm{bcd}$ & $0.5 \pm 1.0 \mathrm{~cd}$ \\
Group II & $266.54 \pm 12.55 \mathrm{ace}$ & $133.89 \pm 20.14 \mathrm{cde}$ & $2.016 \pm 0.23 \mathrm{acde}$ & $0.0 \pm 0.0 \mathrm{cde}$ \\
Group III & $143.23 \pm 9.96 \mathrm{bde}$ & $846.36 \pm 62.17 \mathrm{abde}$ & $0.170 \pm 0.013 \mathrm{abe}$ & $4.0 \pm 0.0 \mathrm{abe}$ \\
Group IV & $292.21 \pm 14.88 \mathrm{ace}$ & $591.80 \pm 29.76 \mathrm{abc}$ & $0.495 \pm 0.038 \mathrm{abe}$ & $4.0 \pm 0.0 \mathrm{abe}$ \\
Group V & $460.51 \pm 19.80 \mathrm{abcd}$ & $540.23 \pm 50.27 \mathrm{abc}$ & $0.857 \pm 0.076 \mathrm{bcd}$ & $1.3 \pm 0.5 \mathrm{bcd}$ \\
\hline
\end{tabular}

Group I (negative control). Group II (negative control + ozonized cosmetic formulation). Group III (positive control). Group IV (positive control + unozonized formulation). Group V (positive control + ozonized cosmetic formulation). aP $<0.05$ compared to group I (negative control). $\mathrm{b} P<0.05$ compared to group II (negative control + ozonized cosmetic formulation). $\mathrm{c} P<0.05$ compared to group III (positive control). $\mathrm{d} P<0.05$ compared to group IV (positive control + unozonized formulation). e $P<0.05$ compared to group V (positive control + ozonized cosmetic formulation).

1995), (Mulero et al., 2006). In this study a notable improvement was observed in the antioxidant response of those animals treated with the ozonized cosmetic formulation (Calabuig and Gutiérrez, 2004), (Díaz and Hernández, 2008). The combined function of the enzymes catalase and superoxide dismutase can be observed: in the positive control group (group III) there is a significant increase in catalase activity which corresponds to the increase in the levels of hydrogen peroxide (obtained from the detoxification of the superoxide anion), while at the same time this hydrogen peroxide inhibits the activity of the superoxide dismutase. However, in the positive control group treated with the ozonized cosmetic formulation (group $\mathrm{V}$ ), there is a recovering of the superoxide dismutase activity as a result of the 
decrease in hydrogen peroxide levels and catalase activity returns to the normal levels (no significant difference regarding the negative control group I). Similar results were described by (Martínez et al., 2001) who report a significant increase in the activity of SOD in animals treated with ozone therapy. In addition (Calunga et al., 2005) also report a significant increase in the enzymes of the antioxidant defense system in animals treated with ozone therapy.

The increase in the antioxidant enzyme activities along with the decrease in the levels of the oxidant biomarkers MDA and THP is evidence of the protecting effect of the cosmetic formulation for oxidative stress in the skin. Other authors (Calunga, 2005; Zamora, 2005) report a significant decrease in the oxidant biomarkers and an improvement in the antioxidant defence system in groups of animals treated with ozone gas before experimental subtotal nephrectomy or endotoxic shock. The unexpected behavior of conjugated dienes could be due to the transitory character of these compounds since they are intermediate products of lipid peroxidation and in the presence of oxygen, react very rapidly to form lipoperoxidic radicals. It is quite probable that the highest values of CD concentration in the damaged groups (III, IV and V) might be determined in a shorter time period than the five days established in our study, which matches with results reported by (Mulero, 2006) about the transitory character of conjugated dienes.

Additionally, data obtained from determination of all these parameters (oxidant and antioxidant biomarkers) were thoroughly processed by the oxidative stress diagnosis system, because the oxidative stress grade is not determined by a single enzyme or one or two oxidant biomarkers, it is the global result of the combination of all these parameters which has to be taken into account. By means of this system it can be observed that the balance of total oxidant and antioxidant activities (the redox index) gave a very low value for the positive control group, followed by the positive control plus unozonized formulation group.

In general, animals treated with the ozonized cosmetic formulation showed the lowest oxidative stress grade (groups II and V). Oxidant activity, as well as oxidative stress grade, is higher in group $V$ than in group I; however this result is expected since group I did not suffer an oxidative injury.

\section{CONCLUSSION}

These results showed that the studied formulation is capable of stimulating the antioxidant defense system, protecting skin against oxidant radiation. Therefore, $10 \%$ ozonized theobroma oil formulations can be used as a new and effective cream for solar protection.

\section{REFERENCES}

Álvarez A. Consecuencias del estrés oxidativo en la piel por radiaciones ultravioleta. 1995. Rev. Cubana Invest. Biomed. 14, ene-dic.
Bocci V. 2005. Ozone a new medical drug. Springer, Netherlands.

Calabuig PA, Gutiérrez T. 2004. Composiciones que contienen aceites naturales ozonizados. EPO 2211 341, A61K 31/327.

Calunga JL, Zamora ZB, Borrego A, Río S, Barber E, Menéndez S. 2005. Ozone Therapy on Rats Submitted to Subtotal Nephrectomy: Role of Antioxidant System. Mediat. Inflamm. 4, 221-227.

Díaz M, Martínez G, Arteaga M, Garcés R. 2006a. Chemical Analysis of Ozonized Theobroma Fat. J. Am. Oil Chem. Soc. 83, 1-4.

Díaz M, Hernández R, Martínez G, Vidal G, Gómez M, Fernández H, Garcés R. 2006b. Comparative Study of Ozonized Olive Oil and Ozonized Sunflower Oil. J. Brazil Chem. Soc. 7, 403-407.

Díaz M, García K, Sánchez Y, Hernández F, García L, Meneau RI, Gómez M, Fernández LA, Sánchez E, Gil D, García G, Piña Y, Díaz A, Rosabal M, Manet BM, Nicolás PD. 2008. Registro sanitario Crema Suavizante, Marca: Ozonol No. 074/08, Tomo: LX y Folio: 074.

Díaz M, Hernández F. 2008. Estrés oxidativo en el envejecimiento. Uso de las sustancias ozonizadas. Monografía.com http:/www.monografías.com/trabajos57/ estrés-oxidativo/estrés-oxidativo.shtml.

EEC. 1979. Methods for the determination of toxicity. Council Directive 79/831/EEC, 18 September, Annex V, Part B, Annex VII, 4.1.5.

Faraji B, Kang HK, Valentine JL. 1987. Methods compared for determining glutathione peroxidasa activity in blood. Clin. Chim. Acta 33, 539-543.

Gerard-Moonier D, Erdelmeier I, Regnard K, MozeHenry N, Yadan JC, Chaudiere J. 1998. Reactions of 1-methyl-2-phenylindone with malondialdehyde and 4-hydroxyalkenals. Analytical applications to a colorimetric assay of lipid peroxidation. Chem. Res. Toxicol. 11, 1176-1183.

Guanche D, Hernández Frank, Zamora Z, Alonso Y. 2009. Sistema de diagnóstico computarizado para la clasificación del estrés oxidativo en un modelo de sepsis peritoneal en ratas. Rev. CENIC C. Biol. 40, 83-87.

Hasbún S, Díaz de la Roche A, Díaz M. 2005. Utilización de una crema cosmética ozonizada en la involución cutánea. Tesis Presentada por el Título de Especialista en Dermatología. Ciudad de La Habana. Cuba.

Hernández F. 2006. Registro del Sistema para el Diagnóstico del Estrés Oxidativo. Registrado en el Centro de Derecho de Autor de la Republica de Cuba, 1313.

Hernández F. 2007. To What Extent Does Ozone Therapy Need a Real Biochemical Control System? Assessment and importance of oxidative stress. Arch. Med. Res. 38, 571-578.

Lowry O, Rosebrough H, Farr AL, Randall RJ. 1951. Protein measurement with the folin phenol reagent. $J$. Biol. Chem. 193, 265-275.

Martínez G, Candelario E, Menéndez S, Lamberto R, Giulianni A, León OS. 2001. Ozone Treatment Reduces Markers of Oxidative and Damage Endothelial in an Experimental Diabetal Model in Rats. Pharmacol. Res. 44, 391-396.

Menéndez S, González R, Ledea O, Hernández F, Díaz M. 2008. Ozonoterapia aspectos básicos y sus aplicaciones clínicas. Editorial CENIC. Ciudad Habana, Cuba.

Minami M, Yoshikawa HA. 1979. Simplified assay method of superoxide dismutase activity for clinical use. Clin. Chim. Acta 92, 337-342. 
Molerio J, Menéndez S, Ledea O, Díaz M, Rubí D, Fernández A, Lezcano I. 2005. Method for obtaining ozonized oils and vegetable fats and use of said products for pharmaceutical and cosmetic purposes. Sudáfrica No. 2004/8856, PCT/CU03/00003. WO 03/085072 A1.

Mulero M, Romeo M, Giralt M, Folch J, Nogues MR, Fortuno A, Sureda FX, Linares V, Cabre M, Paternain $\mathrm{JL}$, Mallol J. 2006. Oxidative stress-related markers and langerhans cells in a hairless rat model exposed to UV radiation. J. Toxicol. Environ Health A 14, 1371-8.

Packer L. 1994. Vitamin E is nature's master antioxidant. Sci. Med. 1, 54-63.

Pallack RL, Morse, D.R. 1988. Free radicals and antioxidants: relation to chronic disease and aging. Int. J. Phychosom 35, 43-48.

Southorn PA, Powis G. 1988. Free radicals in medicine. I: Chemical Nature and Biological Reactions. Mayo Clin. Proc. 63, 381-389.

Statistic. 2003. Release: 6 Copyright Statsoft. Inc: All rights reserved.
Vanlente F, Pepoy M. 1990. Coupled-enzyme determination of catalasa activity in erythrocytes. Clin. Chim. Acta 36, 1339-1343.

Vasankari T, Kujala U, Heinonen O, Kapanen J, Aqhotupa M. 1995. Measurement of serum lipid peroxidation during exercise using three different methods: diene conjugation. thiobarbituric acid reactive material and flouroscent chromolipids. Clin. Chim. Acta 234, 63-69.

Wolff SP. 1994. Ferrous ion oxidation in the presence of the ion indicator xylenol orange for the measurement of hydroperoxides: the FOX assay. Method Enzymol. 233C, 182-189.

Zamora Z, Borrego A, López OY, Delgado R, González R, Menéndez S. 2005. Effects of Ozone Oxidative Preconditioning on TNF- $\alpha$ Release and AntioxidantProoxidant Intracellular Balance in Mice During Endotoxic Shock. Mediat. Inflamma 1, 16-22.

Recibido: $10 / 5 / 10$ Aceptado: 18/8/10 